\title{
CURRENT STATUS OF AMBEWELA RESERVOIR OF SRI LANKA WITH SPECIAL REFERENCE TO WATER POLLUTION
}

\author{
K.A.W.S Weerasekara *, A.A.D. Amarathunga, R. R. A. R Shirantha, N Sureshkumar and \\ S. A. M. Azmy
}

National Aquatic Resources Research and Development Agency (NARA) Sri Lanka

E mail: shyamalikaww@nara.ac.lk

\begin{abstract}
The water pollution trends in the Ambewela reservoir at the uppermost catchment of Kotmale River was assessed through a study on chemical and bio monitoring programme that carried out from March to October 2008.
\end{abstract}

The mean average value (mean \pm SD) of the nitrate, nitrite, phosphate and ammonia concentrations in Ambewela reservoir were $0.780 \pm 1.386 \mathrm{mg} / \mathrm{l}, 0.103 \pm 0.223 \mathrm{mg} / \mathrm{l}, 0.051 \pm 0.061 \mathrm{mg} / \mathrm{l}$ and $0.218 \pm$ $0.261 \mathrm{mg} / \mathrm{l}$ whereas values for the streams selected from Dambagasthalawa Oya were $0.985 \pm 0.902$ $\mathrm{mg} / \mathrm{l}, \quad 0.099 \pm 0.207 \mathrm{mg} / \mathrm{l}, \quad 0.038 \pm 0.026 \mathrm{mg} / \mathrm{l}$ and $0.085 \pm 0.077 \mathrm{mg} / \mathrm{l}$ respectively. Average Chlorophyll- $a$ values of the reservoir were $17.85 \pm 17.858 \mathrm{mg} / \mathrm{m}^{3}$ and $8.30 \pm 4.686 \mathrm{mg} / \mathrm{m}^{3}$ for other two streams accordingly. Average BOD values of the reservoir were $8.06 \pm 3.494$ and $4.25 \pm 2.251$ for other two streams correspondingly.

The bio monitoring studies also clearly showed sudden records of huge colonies of Hydra (approximately $258 / \mathrm{cm}^{3}$ ) in the reservoir from time to time. This phenomenon was found in relatively dry period that directly coincided with intensified use of agro chemicals. Moreover, steady population of Chironomid (average population density $208 / \mathrm{cm}^{3}$ ) that is commonly accepted pollution indicator was reported at Ambewela reservoir throughout the study period.

Therefore, both chemical and bio monitoring studies indicate eutrophic condition in Ambewela reservoir in which long run might affect on the ecology of the entire ecosystem. Hence prompt mitigatory action should be implemented to avoid further depletion.

Key Words: Ambewela Reservoir, Water Pollution, Physico-Chemical Parameters, Chlorophyll $-a$

\section{INTRODUCTION}

Freshwater systems such as lakes, rivers and streams are of importance to human as a resource for public health and for clean water for household, industrial and agricultural use. They are also important as living environments for the ecology of many species of animals and plants that inhabit them (Connell 1993).

Of the freshwater ecosystems of Sri Lanka, the Kotmale sub catchment of the Mahaweli river system is very significant since it is the major supplier of direct drinking, agricultural, irrigational and hydropower water for the people especially in the central high hills. Despite its aquatic health is depleting now due to a number of human activities (De Silva \& De Silva 1994). The Ambewela reservoir is a man made tank (Arumugum 1969) located in the particular catchments. Its upper catchment area is of few perennial streams (figure 1.1) which originate in Northern slope of the Totapola mountain range that run through Pattipola area. However, its middle catchment is of more annual crop lands, outsized poultry farms and a little forest stretch. The reservoir routinely gets agricultural effluent water that 
rich in organic and chemical pollutants from neighbouring animal farms and cropped areas. For this reason there is an enormous possibility to experience a rapid water quality depletion trend in the reservoir. Further, there are no published records in the Ambewela reservoir to study the water pollution trends using both APHA standards methods chemical and bio monitoring procedures. Thus, the present study was carried out through a comprehensive study on its chemical and biological environments to quantify its current water pollution trends.

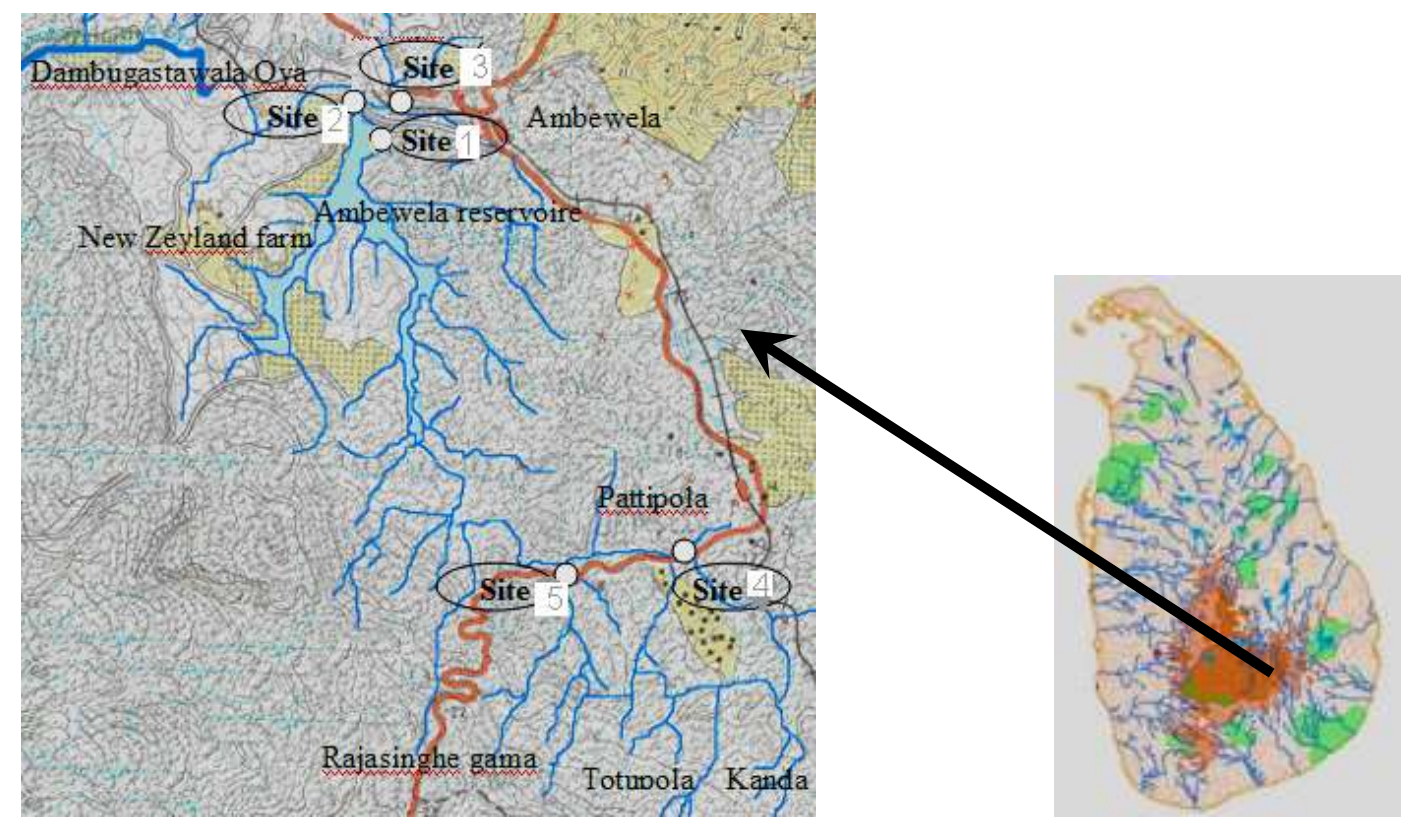

Figure 1.1: map of Sri Lanka showing location of the Ambewela Reservoir, Dambagasthalawa River and the study sites.

\section{MATERIAL AND METHODS}

\subsection{CHEMICAL MONITORING PROCEDURE}

The study was carried out from March 2008 to October 208 in five study sites; three selected sites in the Ambewela reservoir (site1: right side sluice gate of the Ambewela reservoir, site 2: reservoir spill, site 3: the most upper outlet canal of the reservoir) and two selected upstream sites from the Dambagasthalawa Oya (site 4: little disturbed $3^{\text {rd }}$ order stream at Pattiopola area, site: 5 undisturbed $3^{\text {rd }}$ order perennial stream at off Pattipola). Study area was selected using 1:50,000 scale topographic maps \& according to stratified random sampling techniques. Each site was monthly visited and monitoring studies were carried out.

A total of fourteen physico-chemical parameters were studied in chemical monitoring programme to identify water pollution trend. Eight physical properties (air temperature, water temperature, $\mathrm{pH}$, electrical conductivity, total suspended solids, total dissolved solids, turbidity, dissolved oxygen), four nutrient parameters (ammonia-nitrogen, nitrate-nitrogen, nitrite-nitrogen and orthophosphate), one organic constituent (5-day biochemical oxygen demand) and the chlorophyll- $a$ content as a biological indicator were studied.

Physical properties were measured in in situ and other physico-chemical parameters were analyzed in the laboratory. The Aqua Lytic BOD sensors were used to study Bio-Chemical Oxygen Demand. pH was measured using a portable $\mathrm{pH}$ meter (Orion 260A), electrical conductivity was measured using HANNA portable multi range conductivity meter (model HI 8733), dissolved oxygen levels were measured using a (Orion 830A) portable dissolved oxygen meter, turbidity level was measured using a (HACH 2100P) portable turbidity meter. Chlorophyll - a analyses was conducted in accordance 
with APHA $10200 \mathrm{H}$ standards method. All other laboratory analyses were conducted in accordance with APHA standards methods (APHA, 1998). Microsoft Excel software package was used for analyses of the data (table 2.1) to identify and quantify the prevailing pollution trend. In addition, the study was also focused to seek and identify the cause and effect to quantify the reasons for water quality depletion.

\subsection{BIO MONITORING PROCEDURE}

For the biological monitoring studies, the population densities of four selected bio-indicative invertebrate taxa namely Hydra, chorinomid larvae (order diptera), Helicopsyche (order trichoptera) and Heptagenia (order ephemeroptera) were studied through a random sampling technique. Here the selected macro invertebrates that colonized/attached on five randomly selected bed boulders/benthic samples (approximately $3 \mathrm{~cm} \times 4 \mathrm{~cm}$ in diameter) were collected into a white enamel tray using a fine meshed paint bush and forceps. Later they were sorted out and their abundances were calculated as follows.

$$
\text { Abundance }=\text { number of individuals/area of surveyed }\left(\mathrm{m}^{2}\right)
$$

\section{RESULTS}

\subsection{RESULTS OF CHEMICAL MONITORING}

The maximum, minimum and average values for some physico-chemical parameters measured in Ambewela reservoir and Dambagasthalawa streams are given in table 3.1. The air temperature values of the reservoir varied from 16.5 to $29.0{ }^{\circ} \mathrm{C}$ whereas it was found to vary from 15.0 to $25.0{ }^{\circ} \mathrm{C}$ at stream sites. The average water temperature values for two waters were $19.43 \pm 1.688$ and $16.87 \pm 1.219$. The $\mathrm{pH}$ values varied between 5.56 to 8.50 and 5.74 to 7.74 in reservoir and stream sites respectively showing a slightly alkaline condition in reservoir sites. The lowest dissolved oxygen value $(1.43 \mathrm{mg} / \mathrm{l})$ was also recorded from a reservoir site whereas others recorded considerably high dissolved oxygen levels. However, in relatively dry period of the year i.e. in June and October it was deviated. Electrical conductivity values of the reservoir sites varied from 20.2 to $37.6 \mu \mathrm{S} / \mathrm{cm}$ whereas 19.79 to $40.8 \mu \mathrm{S} / \mathrm{cm}$ for Dambagasthalawa stream sites.

Turbidity values of the reservoir sites varied between 2.21 to $12.40 \mathrm{NTU}$ and 0.54 to $4.10 \mathrm{NTU}$ for stream sites. Maximum turbidity value was recorded at study sitappro $12.40 \mathrm{nimm}$, urbidity value TJETBT1 00172 
Table 3.1: Maximum, minimum and average values for some physico-chemical parameters of the Ambewela reservoir and Dambagasthalawa streams (average of site 04 and site 05) in 2008.

\begin{tabular}{|c|c|c|c|c|c|c|c|c|}
\hline \multirow{2}{*}{$\overline{\text { Parameter }}$} & \multicolumn{4}{|c|}{ Ambewela reservoir } & \multicolumn{4}{|c|}{ Dambagasthalawa streams } \\
\hline & Max. & Min. & Avg. & Stdv. & Max. & Min. & Avg. & Stdv. \\
\hline Air temperature $\left({ }^{\circ} \mathrm{C}\right)$ & 29.0 & 16.5 & 20.86 & 3.7 & 25.0 & 16.0 & 19.84 & 3.9 \\
\hline $\begin{array}{l}\text { Water temperature } \\
\left({ }^{\circ} \mathrm{C}\right)\end{array}$ & 22.70 & 16.9 & 19.44 & 1.7 & 19.0 & 15.0 & 16.87 & 1.2 \\
\hline $\mathrm{pH}$ & 8.50 & 5.56 & 7.09 & 0.8 & 7.74 & 5.74 & 6.92 & 0.5 \\
\hline $\mathrm{DO}(\mathrm{mg} / \mathrm{l})$ & 8.82 & 1.43 & 6.13 & 2.1 & 8.40 & 6.67 & 7.45 & 0.5 \\
\hline BOD $(\mathrm{mg} / \mathrm{l})$ & 18.0 & 4.0 & 8.06 & 3.4 & 8.0 & 1.0 & 4.25 & 2.3 \\
\hline $\mathrm{EC}(\mu \mathrm{S} / \mathrm{m})$ & 37.60 & 20.20 & 27.16 & 5.1 & 40.8 & 19.79 & 30.53 & 6.1 \\
\hline $\begin{array}{l}\text { Ammonia } \quad \text { cal-N } \\
(\mathrm{mg} / \mathrm{l})\end{array}$ & 0.851 & 0.004 & 0.218 & 0.3 & 0.230 & 0.005 & 0.085 & 0.078 \\
\hline Nitrite-N (mg/l) & 0.760 & 0.0007 & 0.103 & 0.2 & 0.649 & 0.0003 & 0.099 & 0.207 \\
\hline Nitrate-N (mg/l) & 5.82 & 0.010 & 0.780 & 1.4 & 2.230 & 0.010 & 0.985 & 0.902 \\
\hline Phosphate (mg/l) & 0.306 & 0.0036 & 0.051 & 0.06 & 0.083 & 0.0031 & 0.038 & 0.026 \\
\hline TSS (mg/l) & 10.00 & 1.50 & 4.39 & 2.6 & 8.00 & 0.50 & 3.15 & 2.7 \\
\hline Turbidity (NTU) & 12.4 & 2.21 & 5.85 & 2.8 & 4.10 & 0.54 & 1.29 & 0.9 \\
\hline TDS (mg/l) & 15.70 & 9.20 & 12.04 & 2.2 & 19.00 & 8.90 & 13.93 & 3.1 \\
\hline $\begin{array}{l}\text { Chlorophyll } \\
\left(\mathrm{mg} / \mathrm{m}^{3}\right)\end{array}$ & 62.26 & 2.05 & 17.85 & 17.9 & 18.77 & 2.04 & 8.30 & 4.7 \\
\hline
\end{tabular}

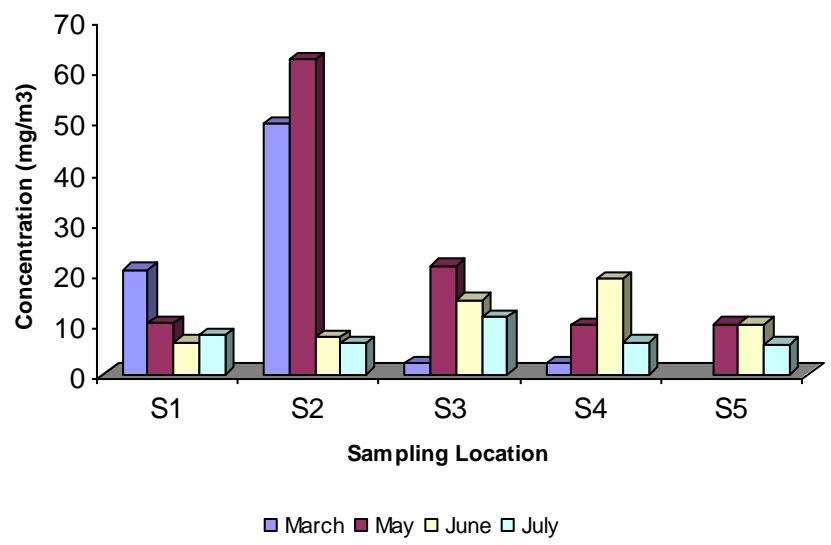

Figure 3.1: Monthly variations in Chlorophyll- $a$ concentration of the study sites in the Ambewela Reservoir and Dambagasthalawa streams studied in 2008. 


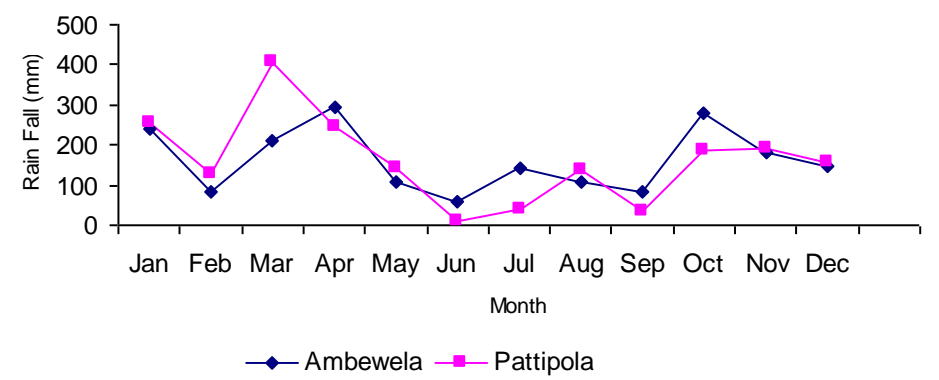

Figure 3.2: Monthly rainfall variations in Ambewela and Dambagasthalawa stream area in 2008 (Source: Meteorological Department, Colombo)

BOD values in reservoir sites varied from 04 to $18 \mathrm{mg} / \mathrm{l}$ while it was vary from 01 to $08 \mathrm{mg} / \mathrm{l}$ at stream sites. The chlorophyll- $a$ concentration at the reservoir sites were ranged from 2.05 to 62.26 $\mathrm{mg} / \mathrm{m}^{3}$ where the average value was $17.85 \pm 17.858 \mathrm{mg} / \mathrm{m}^{3}$. It varied from 2.04 to $18.77 \mathrm{mg} / \mathrm{m}^{3}$ at the stream sites with average of $8.30 \pm 4.686 \mathrm{mg} / \mathrm{m}^{3}$. In May 2008 considerably higher chlorophyll- $a$ concentrations were recorded at all the study sites and it was highest $\left(62.258 \mathrm{mg} / \mathrm{m}^{3}\right)$ at the study site 2 . However, the chlorophyll- $a$ content average for entire the reservoir was significantly high indicating an associated risk of having eutrophic condition.

\subsection{RESULTS OF BIO MONITORING}

The sites vice records of selected bio indicative taxa that were collected through present bio monitoring procedure are given in table 3.2 and their sites vice mean population density variation is also showing in figure 3.3. Of the studied insect bio indicative taxa the ephemeropteran and tricopteran were predominantly recorded at all the stream sites with high population densities. However, they were not recorded at the reservoir sites. But chironomid dipteran was predominantly found in the reservoir sites 1 and 3. At the site 3 its population was found to steady with 208 individuals $/ \mathrm{m}^{2}$ average density. In addition to chironomid larvae these two reservoir sites occasionally especially in May, June and September recorded huge colonies of Hydra, a well accepted bio indicator especially in organically polluted waters.

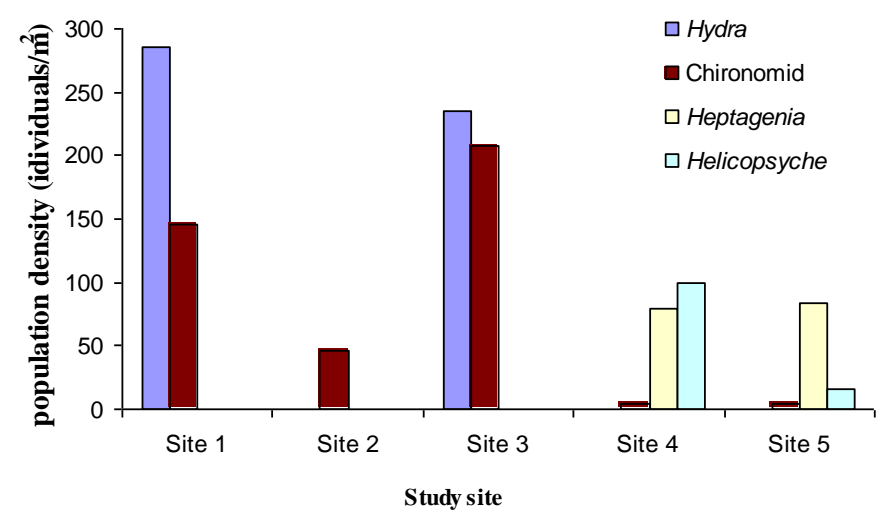

Figure 3.3: Variations in mean population densities of the bio indicative taxa assessed at each study site in the Ambewela reservoir area in 2008 
Table 3.2: Records of the selected bio indicative taxa at each study site in the Ambewela reservoir and the streams selected (+ indicates present and - indicates absent).

\begin{tabular}{|l|l|l|l|l|l|}
\hline Invertebrate taxa & $\begin{array}{l}\text { Site 1 } \\
\text { (Reservoi }\end{array}$ & $\begin{array}{l}\text { Site 2 } \\
\text { (Reserv }\end{array}$ & $\begin{array}{l}\text { Site 3 } \\
\text { (Reservoi }\end{array}$ & $\begin{array}{l}\text { Site 4 } \\
\text { (Stream) }\end{array}$ & $\begin{array}{l}\text { Site 5 } \\
\text { (Stream }\end{array}$ \\
\hline Arthropod taxa & & & & & \\
\hline Order Trichoptera & & & & & \\
\hline Helicopsyche & - & - & - & +++ & + \\
\hline Order Ephemeroptera & & & & & \\
\hline Heptagenia sp. & & & & & \\
\hline Order Diptera & - & - & - & ++ & - \\
\hline Chironomid larvae & & & & & \\
\hline Cnidarian taxa & +++ & ++ & ++++ & + & + \\
\hline Hydra sp. & & & & & \\
\hline
\end{tabular}

\subsection{POSSIBLE CAUSES IDENTIFIED AS REASONS FOR WATER QUALITY DEPLETION IN THE STUDY AREA}

During the present eco-monitoring programme, the study team could observe and identified definite causes that could bring detrimental effect on quality of water at the study sites and for rapid low down of the ecological integrity of the Ambewela reservoir. Converting forest area into annual cropped or tea area obviously cause soil erosion, high siltation and habitat loss. The excessive use of agrochemicals, use of organic and inorganic fertilizers, mixing poultry animal dung and other waste with waters, dumping waste due to eco-tourism loading bio and non bio degradable substance into water bodies and natural habitats, timber felling of plantation forests creating high organic matter content which need substantial time to degrade and, lack of good vegetation cover in bankers of the stream creating eroding of bankers.

\section{DISCUSSION}

During the present study the recorded mean values for $\mathrm{pH}$, electrical conductivity, dissolved oxygen level, total dissolved solids and nitrate-N levels in the assessed catchment sites are within the limit of proposed ambient water quality standards for inland waters of Sri Lanka (CEA 2001). However, the values for turbidity, BOD and nitrite-N have exceeded the limits of specifications cited in Sri Lanka Standards Institute No. 614 part 1 (1983) for potable water. Yet no specific water quality standards developed for Total Suspended Solids in Sri Lanka to compare with the present values. 
Through out the study period there were records of elevated levels of chlorophyll-a concentration at the Ambewela reservoir sites (average value of $17.85 \pm 17.858 \mathrm{mg} / \mathrm{m}^{3}$ ). On the other hand the orthophosphates levels in reservoir sites are relatively higher than stream sites. These two parameters are indicating a possibility of eutrophic conditions. The highest chlorophyll-a concentration recorded at Ambewela reservoir was $62.258 \mathrm{mg} / \mathrm{m}^{3}$ in May. The highest BOD value that is standard tests used to describe the pollution status of water with respect to organic matter recorded from the reservoir site was $18 \mathrm{mg} / \mathrm{l}$ in June in site 3 .

The cause and effect studies showed possible sources for water quality depletion of the study area, Among them excessive use of agrochemicals both organic and inorganic fertilizers, mixing poultry animal dung and other waste with waters, dumping waste due to eco-tourism loading bio and non bio degradable substance into water bodies and natural habitats, timber felling of plantation forests creating high organic matter content which need substantial time to degrade might be possible reasons to experience high $\mathrm{BOD}$ values and high chlorophyll- $a$ concentrations in the reservoir indicating an eutrophic waters.

Anthropogenic or cultural eutrophication is most frequently caused by the fertilization of water with nutrients especially phosphorous in sewage that contains phosphorous rich detergents, human waste and/or animal wastes and agricultural run off contaminated by fertilizers. These anthropogenic influences have affected lakes and other surface waters wherever the human population density is large or agricultural land use is intensive (Bill, 1995).

Land use is probably the greatest factor influencing changes in TSS or turbidity levels in water bodies.As, watersheds develop, there is an increase in disturbed areas such as croplands, a decrease in vegetation, and increases in the rate of runoff. These all cause increase in erosion, nutrients which in turn to promote algal growth cause to create nutrient rich waters.

In addition to those the farmers in riparian area were found to having three annual crop seasons per year. They cultivate potato, cabbage, beans, leeks, radish and flowering plants thrice a year. Therefore, one farming season limits to three months. From tilling to harvesting stage crop lands are very frequently expose to different agrochemicals such as weedicides, fungicides, insecticides etc. Residues of such chemicals rapidly go into adjoined water bodies thereby into a nearby reservoir and streams. This probably increased level of toxic compound in water. In addition to this farmers constantly use some crop manure in excess. This excess amount or sometimes all if it is raining at applying time washed away into a near by water bodies. This increases the level of nutrients in water bodies and then leads to have an eutrophication condition within a very short period. Eutrophication of water body generally results in changes in population and activity of numerous living organisms. In fact, heavy eutrophication may cause a distinct reduction in the number of plants and animal species in the water (Amarasiri, 2008).

The chemical monitoring results are further elucidated by present bio monitoring study, as pollution indicative taxa such as Hydra and Chironomid (Mason 1996) were observed thriving in large numbers within the reservoir during the months of June to September with relatively lower rainy conditions (figure 3. 3) might be due to concentrated water body aggravating the situation. In reservoir sites there were no any records of good water quality indicative insects such as heptageniids and Helicophsyds that obviously live in freshwater waters of good ecological integrity (Mason 1996). However, they were found in all the upstream sites studied that are flowing through natural/semi natural forest area. The absence of such insect taxa in the reservoir sites can possibly due to their low abundance or entirely absence in the study area. Therefore, it is reasonable to conclude that there is depletion in environment integrity at the reservoir mainly due to organic pollution.

Proceedings of the 15 $5^{\text {th }}$ International Forestry and Environment Symposium, 26-27 November 2010.

Published by Department of Forestry and Environmental Science, University of Sri Jayewardenepura, Sri Lanka. 
Hence, more comparable results have been obtained in present concurrently performed chemical and bio monitoring programmes. So that it is logical to conclude that Ambewela reservoir is now in a most liable step of eutrophication condition. This environmental degrading affect on healthiness of the entire catchment as the Dambagastalawa river is among tributary network of the Kotmale river.

\section{CONCLUSION}

Results of the chemical and bio monitoring studies indicate comparable picture on current status of the Ambewela reservoir revealing that it is having a periodic eutrophic condition especially in relatively dry season in which long run might be affected its ecological integrity of the entire ecosystem and prompt actions should be implemented to avoid further depletion.

\section{RECOMMENDATIONS}

Cost effective technologies are scarce for the reduction of high levels of nutrients and other water pollutants in water bodies. The strategy of water quality management must be shifted from cure to prevention. In addition, reductions of anthropogenic inputs of phosphorous and also other nutrient inputs should be encouraged. Introduction of meaningful legislation and enforcement of laws for minimizing water pollution is urgently required.

\section{ACKNOWLEDGEMENTS}

The authors wish to acknowledge the competent technical assistance provided by the staff of Environmental Studies Division and Inland Aquatic Resources \& Aquaculture Division of NARA. Forest Department, Survey Department and Mahaweli Authority of Sri Lanka, are also greatly acknowledged.

\section{REFERENCES}

Amarasiri, S. (2008). Caring for water. Pp10-127.

Arumugum, S. (1969), “Water resources of Ceylon”, Water Resources Board, Colombo, Sri Lanka.

American Public Health Association (1998) .Standards Methods for the Examination of Water and Wastewater, $20^{\text {th }}$ Edition.washington, D.C, USA: APHA/AWWA/WEF.

Bill Freedman, (1995).Environmental Ecology. ( $2^{\text {nd }}$ Ed.).The ecological effects of pollution, disturbance, and other stresses.pp190.

Central Environmental Authority. 2001. Proposed Ambient Water quality Standards for Inland Waters Sri Lanka.

Connell, D.W. (1993).Water Pollution: causes and effects in Australia and New Zealand ( ${ }^{\text {rd }}$ Ed.).University of Queensland press, St.Lucia.

De Silva, K.H.G.M. \& P. K. De Silva, 1994.The effects of human modification of lotic habitats on the fresh water fauna of Sri Lanka, In: International Association of Theoretical and Applied Limnology, Mitteilungn Communications (Dudgeon, D \& Lam, P.K.S. eds),pp.77-94, No 24.EScheweizerbart'sche Verlagsbuchanglung,Stuttgart.

Mason, C. F. (1996), "Water Pollution Biology". In: Pollution Causes, Effects and Control $3^{\text {rd }}$ Edition (Harrison, R. M. ed.) 66 - 91, The Royal Society of chemistry, University of Birmingham.

Sri Lanka Standards Institute.1983.Drinking water standards.No.614, Part 1 